\title{
EFFECT OF VARIOUS INTER AND INTRA SPACES ON THE YIELD AND QUALITY OF QUINOA (Chenopodium quinoa
} willd.)

\author{
Sief, A. S. ${ }^{*}$; H. R. A. El-Deepah*; A. S. M. Kamel* and \\ Jacline F. Ibrahim ${ }^{\star *}$ \\ ${ }^{*}$ Faculty of Agriculture, Benha University \\ ${ }^{*}$ Field Crops Research Institute Crop Intensification Section A.R.C
}

\begin{abstract}
In order to determine the best planting procedures where three inter spacing (row spacing) and three intra spacing (plant spacing) and their combination. The inter spacing were 20,30 and $40 \mathrm{~cm}$ distances between rows, and the intra spacing between plants were 10,15 and $20 \mathrm{~cm}$ distances between plants and their combinations. Field experiments were conducted at Ismailia Agriculture Research Station, Agriculture Research Center, Ismailia, Egypt during two winter successive seasons of 2012/2013, 2013/2014.

Results indicated that highest grain yield of quinoa was produced when using the narrowest inter species of rows $(20 \mathrm{~cm})$ and the narrowest intra spaces of plants $(20 \mathrm{~cm})$ with significant interaction effect in each of the two seasons. This result could be accepted due to the well even distribution of plants which reduced the compotation for all of prevailing enormous essential requirements of plants as germination seed line emergence, growth and development which reflected on production and quality. A significant reduction of grain yield was obtained by increasing intra spacing between plants i.e.10, 15, $20 \mathrm{~cm}$. This reduction was notical only at the lowest inter spacing of rows at $20 \mathrm{~cm}$. However at wider inter spaces of plant i.e.30 and $40 \mathrm{~cm}$, increases of intra spaces between plants i.e.10,15, $20 \mathrm{~cm}$ cause sub stand increase in grain yield in the first and second seasons with significant differences in the first seasons.

It could be concluded the best treatment for growing quinoa produced from the inter and intra spacing were the lowest. This may be attributed to the appropriate distribution of plants, which decrease completion among plants and allows it to maximum were of the circumstance surrounding it in the caption soil

Keywords: Quinoa, inter and intra spaces, Exotic plants. Chemical constituents of grain.

\section{INTRODUCTION}

Quinoa is a high nutrition food. Its protein quality is much higher than that of other grains. Lysine and amino acid in Quinoa are higher than that in wheat. Its content of amino acid is well-balanced for human and animal feeding, like that of casein. As for iron, phosphorus, potassium, magnesium, zinc, calcium, copper and manganese, they are also higher in quinoa than in corn, and wheat; However, quinoa has a lower sodium content.
\end{abstract}


The marketable seed is usually white. Its leaves are eaten as any leafy vegetable. In the US, the seeds are sold in health food stores at high prices due to their nutritive value.

This crop is drought and salinity tolerant and can grow in sandy soil of aried and semi-aried regions and with other most harmful abiotic adverse factors which affect crop production.

Galwey (1984) reported that seeds are placed in rows in row seeding. When the width of the row is $40-80 \mathrm{~cm}$, seed should be placed at the bottom of the furrow in dry soil or at the top of the ridge in an area with a lot of rain. In south Altiplano, mechanical sowing_is performed with the Satiri drill, which has two furrows with chutes through which the seed is nurtured. He added that the opening of the lines should be adapted to a space between 0.8 and 1 $\mathrm{m}$.

Bubenheim (1991) studied optimum quinoa density using controlled environment hydroponic systems. He demonstrated that dramatic increases in yield and harvest index resulted in part from a higher planting density when compared with average field seeding rates. Further, the higher planting density that is reported for quinoa grown in controlled enviornments is approximately 32 plants $\mathrm{m}^{-2}$.

Oelke et al (1992) found that the field trial in Great Britain indicated that increasing plant density resulted in a slightly earlier maturity. Greater seed also resulted in a slightly earlier maturity. Henderson et al (1993) found that the lowest established population $74000 \mathrm{plant} / \mathrm{ha}$ consistently produced the maximum grain yield. There was no impact of row space at the_lowest population. However, at higher populations, more grain was produced with the wider $(76.2 \mathrm{~cm})$ row spacing. Wider rows, where plants were spaced closer together within each row, increased rivalry at high established populations. Grain yield of the surviving plant was higher as a result of the lowered plant population in the wider rows.

Jacobsen et al (1994) noticed that plots with a row space of $50 \mathrm{~cm}$. which were hoed gave a more yield than plots with 25 or $12.5 \mathrm{~cm}$ row spaces, which were unhoed. The yield increased when changing from combined harvesting to swathing unhoed.

Aufhammer et al (1995), Myers and pertnam (1998), and Gimplinger et al (2007) failed to observe growth, yield, and yield component responses to row space.

Meanwhile, Henderson et al (2000) obtained no yield response to row spacing and suggested that the plasticity of grain amaranth morphology may limit its response to seeding rate and row spacing.

Maligawad and patil (2001) reported that grain yield increased with the increase in the plantpopulation. A study at Thomas Jefferson Agriculture Institute in Missouri, comparing different row spaces, showed that wider row spacing produced the higher most yield. Important interaction for green forage yield and dry matter yield was recorded when using $30 \mathrm{~cm}$ row spaces. The next important higher interaction for green forage yield and dry matter yield was recorded when using $45 \mathrm{~cm}$ row spaces. The row spaces of $45 \mathrm{~cm}$. recorded important higher net returns and benefit cost ratio compared 
to row space of $30 \mathrm{~cm}$. Rojas et al (2004) reported that sowing is an important initial step for planting quinoa. The crop can be planted in either rows or groups and by either broadcasting or transplanting.

Rojas et al (2004) reported that sowing is an important initial step for planting quinoa. The crop can be planted in either rows or groups and by either broadcasting or transplanting.

But Schlick and Bubemheim (2005) researched "yield per unit area, harvest index and biomass accumulated data". They said that the ideal field planting density for quinoa is 640 plant $\mathrm{m}^{-2}$

Spehar and Rocha (2009) studied the effect of densities varying between $100 \times 10^{3}$ to $600 \times 10^{3}$ plants $\mathrm{ha}^{-1}$ on yield and interrelated parameters. In the highest density, the number of observed branching was smaller, when compared to low density. Moreover, plants in great density reached maturing_slightly earlier than in low density, for every increment of 100.000 plants ha ${ }^{-1}$ there was a reduction of $4.0 \mathrm{~cm}$ in plant height. Further, they indicated that these results illustrate the ability of quinoa to compensate for high density. They concluded that the height of the plant shows reduction with increasing density, in the $50 \mathrm{~cm}$ row spacing, when population increases from 100.000 to 600.000 plant ha $^{-1}$. Plants at low densities tended to increase branching to fill the gaps and to delay maturity.

In a recent study, the effect of phosphorus fertilizer and intra row spacing on the growth and yield of grain Amaranth (Amaranth cruentus) was

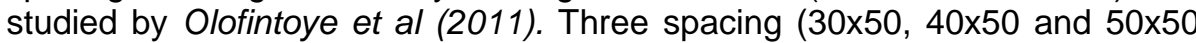
$\mathrm{cm}$ ) resulted in the highest plant height, number of leaves, dry matter yield, biological yield and grain yield. They explained that inferiority of growth, yield and yield component traits was due to inter and intra competition among the planted seeds.

Smith a patel et al (2011) reported that the row spacing of $45 \mathrm{~cm}$ recorded significant higher green forage yield $\left(36,77 \mathrm{tha}^{-1}\right)$, higher dry matter yield $\left(2.33 \mathrm{t} \mathrm{ha}^{-1}\right)$ as compared to $30 \mathrm{~cm}$ row spacing. In interaction significantly higher green forage yield $\left(43.53 \mathrm{t} \mathrm{ha}^{-1}\right)$ and dry matter yield (3.01 $\mathrm{t} \mathrm{ha}^{-1}$ ) was recorded in $45 \mathrm{~cm}$ row spacing. He recorded that the superiority of $45 \mathrm{~cm}$ spacing was mainly due to significant higher total fresh weight and higher number of leaves, higher leaf area and total dry matter accumulation.

Row spacing and plant density in field experiments were performed in different regions of the world according to the diverse agro climatic conditions as the following example show:- In England, 20, 40 and $80 \mathrm{~cm}$ row spaces with plant seeds rates of 15,20 and $30 \mathrm{~kg} / \mathrm{ha}$, respectively. Row spacing 25 $\mathrm{cm}$ in the Netherlands of 0.7 grain seeds/ha; row spaces of $30 \mathrm{~cm}$ seeding rate. In India of 30 plants $/ \mathrm{m}^{2}$ in $30 \mathrm{~cm}$ row spacing $150 \mathrm{~cm}$. In Chili of seeding rate of $25 \mathrm{~cm}$ plants. Its plants spaces, rows spaces of $25,50 \mathrm{~cm}$ in Denmark of $200 \mathrm{plants} / \mathrm{m}^{2}$ (Atul Bhargavaand Shilpi. srivastava 2013).

\section{MATERIALS AND METHODS}

Two field experiments were conducted at Ismaillia Experiment research station to study the effect of seeding in inter and intra spacing on 
the vegetative growth, behaverious, grain yield and yield components of chenopodium quinoa grain in 2012/2013 and 2013/2014 seasons respectively. Proposed treatments were the combination of three inter spacing (row spacing) and three intra spacing (plant spacing). The treatments were as follow:-

A- Inter spacing treatments.

- $20 \mathrm{~cm}$ between rows.

- $30 \mathrm{~cm}$ between rows.

- $40 \mathrm{~cm}$ between rows.

B- Intra spacing treatments.

- $10 \mathrm{~cm}$ between plants.

- $15 \mathrm{~cm}$ between plants.

- $20 \mathrm{~cm}$ between plants.

Statistical design: The treatments were assigned in split plot design in three replicates. Plot area was $15 \mathrm{~m}^{2}$ sequence meter of 5 meters in length and 3 meters in width.

The preceding crop was peanut in 2013 and 2014 seasons. Quinoa seeds variety Danish KVL 3704 (the Royal Faculty of Agriculture, Copenhagen, Denmark) were sown on the $6^{\text {th }}, 11^{\text {th }}$ of December in first and second, respectively. Calcium super phosphate was added at a rate of $15.5 \%$ $\mathrm{P}_{2} \mathrm{O}_{5}$ per fedden during land preparation. Potassium sulphate was applied at the rate of $100 \mathrm{~kg}$ per fadden $\left(48 \mathrm{~kg} \mathrm{~K}_{2} \mathrm{O}\right)$ during soil preparation. Magnesium sulphate was drilled in rows after seeding emergence (20 days after sowing quinoa seeds) at a rate of $50 \mathrm{~kg} / \mathrm{fed}$. Nitrogen fertilizer was added at a rate of $50 \mathrm{~kg} / \mathrm{feddan}$ in the form of ammonium nitrate $(33.5 \% \mathrm{~N})$.

Quinoa seeds were sown at $5 \mathrm{~cm}$ depth under ground surface, covered with sands and immediately irrigated using sprinklers irrigation which system was at 5 days internals until harvest.

Weedsing practiced as previously mentioned and harvesting was practiced as previously mentioned in the first study.

Studied paramaters:

Yield and yield components, grain yield, and its components: samples of ten plants were taken from each two inner rows of each plot and taken immediately to the laboratory, the flowering manually, then the following traits were measured and recorded.

- Plants height $(\mathrm{cm})$.

- Average number of branches/plant.

- Average of head length/plant (cm.).

- Average of head weight/plant (cm.).

- Grain weight/plant (g).

- Weight of 1000 grain (g).

- Grain yield (kg/feddan). 
Physical and chemical analysisthe soil of the experimental site.

\begin{tabular}{|c|c|c|c|c|c|c|c|c|}
\hline \multirow{2}{*}{\multicolumn{2}{|c|}{\begin{tabular}{|c|} 
Clay $\%$ \\
8.64 \\
\end{tabular}}} & \multicolumn{2}{|c|}{ Slit\% } & \multirow{2}{*}{\multicolumn{2}{|c|}{ Sand\% }} & \multicolumn{3}{|c|}{ Soil texture } \\
\hline & & \multicolumn{2}{|c|}{0} & & 91.36 & \multicolumn{3}{|c|}{ sandy } \\
\hline \multirow{2}{*}{$\mathrm{pH}$} & \multirow{2}{*}{$\begin{array}{c}\mathrm{EC} \\
(\mathrm{dS} / \mathrm{m})\end{array}$} & \multirow{2}{*}{ OM\% } & \multirow{2}{*}{$\begin{array}{c}\mathrm{CaCO} 3 \\
(\%)\end{array}$} & \multicolumn{5}{|c|}{ Macro nutrient } \\
\hline & & & & $\mathrm{N}(\mathrm{mg} / \mathrm{Kg})$ & & $\mathrm{Kg})$ & & $\bar{K}(\mathrm{mg} / \mathrm{Kg})$ \\
\hline 8.45 & 0.20 & 0.15 & 0.64 & 10 & & & & 84 \\
\hline \multicolumn{4}{|c|}{ Soluble Cations (meq/L) } & \multicolumn{5}{|c|}{ Soluble Anions (meq/L) } \\
\hline $\mathrm{K}^{+}$ & $\mathrm{Na}^{+}$ & $\mathrm{Mg}^{++}$ & $\mathrm{Ca}^{++}$ & So4 & $\mathrm{Cl}^{-}$ & & & $\mathrm{CO}^{-}$ \\
\hline 0.09 & 0.7 & 0.9 & 0.9 & 1.37 & 0.78 & & & - \\
\hline
\end{tabular}

Sample preparation for chemical analysis of leaves and seed samples were cleaned and dried using oven air forced at during oven $75^{\circ} \mathrm{c}$ till constant weight before analysis. Whole mature leaves and seeds of quinoa were ground in laboratory hummer mill 120 (per ten instruments $A B$, Huddinge, Sweden) through a 60 mesh screen and stored at $4{ }^{\circ} \mathrm{C}$ in an airtight plastic bottle until needed for analysis.

Determination of nitrogen contents:

The nitrogen determination was condacted using Dumes method and an outomated LECD CN analyzer model CN2000 (Sweaney and Rexroad, 1987).

Crude protein : crude protein content was determined using the Dumas method with the automated LECO CN analyzer model CN 2000 and the protein conversion factor of 5.85 was used (Sweaney and Rexroad, 1987).

Determination of phosphorus contents:

Phosphorus was determined with spectro photometer in the acid digest according to the method described by Troug and Meyer (1993).

Determination of potassium contents:

Potassium was photo metrically determined in the acid digest, Where the method of Brown and Lilleland (1946) was followed.

- Statistical analysis

The measured variables were analyzed by ANOVA using MSTATC statistical packing (Freed, 1991). Mean comparisons were done by using the new multiple range test (Duncan's test) followed by Le Clerg et al (1962).

\section{RESULTS AND DISCUSSION}

\section{1- The effect of row spacing on yield and yield components of quinoa.}

Table (1) revealed that quinoa growth, yield and its components were significantly affected by inter row spacing in each of the two seasons. Further the trend predominated the effect on these traits behaved the same in both season, although the values obtained in 2012 season were conspicuously lower than those obtained in 2013 season.

The results evidenced that plant height slightly decreased with widening distances between rows up to $40 \mathrm{~cm}$. apart but with insignificant difference for plant grown between 20 and $40 \mathrm{~cm}$ in the first seasons. In the second season differences were wider enough to reach the $5 \%$ level of significance and reached the level of significance. These results are in agreement with the result obtained by Spehar and Rocha (2009) who reported that quinoa plant has the ability to compensate for the height for plant densities. 
On other hand, row spacing significantly affected quinoa branching. However, the trend of change was reversed. Branching increased gradually with increasing row spacing from 20 to 30 and $40 \mathrm{~cm}$ between rows. The interpretation is feasible, since growing quinoa at wider rows provides plant with more illumination and less underground competition for nutrient and water. Several investigators reached same results such as Mailigawadit patil (2001) and Smith patel et al (2011). The effect on head length was significant in first seasons but insignificant in the second seasons. there were gradual increases in head length with increasing row spacing from 20 to $40 \mathrm{~cm}$. The effect of row spacing on head weight behaved the same as the means of head length, but was more pronounced in the second seasons.

Grain weight /plant followed the same pattern of change as in the first year but with little deviation in the second seasons where the grain weight of plant grown at $30 \mathrm{~cm}$ row spacing was heavier than plants raised on $40 \mathrm{~cm}$ row spacing. Row spacing had no effect on the weight of 1000 grain in both year. Further the trend of the yield per feddan was contrary to the trend of the yield components to head length, head weight, and grain weight. This contradiction might be due to the increase of number of plants per unit area with dense rowing at $20 \mathrm{~cm}$ apart over rowing at $30 \mathrm{~cm}$ apart and $40 \mathrm{~cm}$ apart. The data revealed decrease in the yield of grain/fed. with increasing row spacing up to the widest. The reductions are estimated to 158.80 and 23.20 $\mathrm{kg}$ of grain when row spacing increased from 20 to $30 \mathrm{~cm}$ in the first and the second sesons. Which equal (26.63 and $3.43 \%)$ and $(431.3$ and $316.5 \mathrm{~kg})$. This calculation indicate that $20 \mathrm{~cm}$ rowing resulted in sharp increases in yield per feddan.. Several workers studied the effect row spacing on growth yield components and yield of grain and defined optimum row spacing as influenced by environmental factor and the variety used such Henderson et al (1993) and Malligawadit and patil (2001).

Table (1): Effect of inter spacing of rows on yield and yield components of quinoa grain.

\begin{tabular}{|c|c|c|c|c|c|c|c|}
\hline $\begin{array}{l}\text { Characters } \\
\text { Row } \\
\text { spacing } \\
\text { (cm) }\end{array}$ & $\begin{array}{c}\text { Plant } \\
\text { height } \\
\text { cm }\end{array}$ & $\begin{array}{c}\text { Branches } \\
\text { No. }\end{array}$ & \begin{tabular}{|c|} 
Head \\
length \\
mean \\
$\mathrm{cm}$
\end{tabular} & $\begin{array}{c}\text { Head } \\
\text { Weight } \\
\text { /plant } \\
\text { g }\end{array}$ & $\begin{array}{c}\text { Grain } \\
\text { Weight } \\
\text { /plant } \\
\text { g }\end{array}$ & $\begin{array}{c}1000 \\
\text { grain } \\
\text { weight }\end{array}$ & $\begin{array}{c}\text { Yield } \\
\mathrm{Kg} / \mathrm{fed}\end{array}$ \\
\hline \multicolumn{8}{|c|}{$1^{\text {st }}$ Seasons $(2012 / 2013)$} \\
\hline 0 & $35.46 \mathrm{a}$ & $9.922 \mathrm{~b}$ & $11.20 \mathrm{c}$ & $15.37 \mathrm{~b}$ & $9.022 \mathrm{~b}$ & $24 \mathrm{a}$ & $596.4 \mathrm{a}$ \\
\hline & & & & & $2 \mathrm{a}$ & $2.24 \mathrm{a}$ & 337.6 \\
\hline & $a$ & & $15.58 \mathrm{a}$ & 21. & $15.03 \mathrm{a}$ & $2.25 \mathrm{a}$ & 165.1 \\
\hline SD 5\% & & 1.28 & 1.13 & \begin{tabular}{|l|}
1.14 \\
\end{tabular} & 2.21 & N.S & 0.03 \\
\hline \multicolumn{8}{|c|}{$2^{\text {nd }}$ Seasons $2013 / 2014$} \\
\hline 0 & $.07 \mathrm{a}$ & $10.07 \mathrm{~b}$ & $14.93 \mathrm{a}$ & $19.04 \mathrm{c}$ & $10.51 \mathrm{~b}$ & $2.35 \mathrm{a}$ & $677.0 \mathrm{a}$ \\
\hline & $44 \mathrm{ab}$ & & $15.06 \mathrm{a}$ & $24.08 \quad b$ & $19.92 \mathrm{a}$ & $2.30 \mathrm{a}$ & \\
\hline 40 & $45.10 \mathrm{~b}$ & & $15.79 \mathrm{a}$ & $29.31 \mathrm{a}$ & $0 \mathrm{a}$ & $2.32 \mathrm{a}$ & $327.3 \mathrm{~b}$ \\
\hline & 4.71 & 2.28 & N.S & 3.89 & 2.71 & N.S & 89.6 \\
\hline
\end{tabular}

The average number of branches per plant behaved the reverse. Differences between the treatments imposed were significant in the first 
season but did not reach the $5 \%$ level of significance in the second seasons. Gradual increase in branching was associated with widening distances between plants supporting the results obtained by Sherif Sahar et al (2005). Head length, head weight and grain weight plant and the weight of 100 grain followed the same pattern of change with increasing distances between plants. The data obtained indicated gradual increases in these traits which represent, the yield components with widening distances between plants up to $20 \mathrm{~cm}$ apart. However, differences in the values of these traits between the moderate and widest distance $(15$ and $20 \mathrm{~cm}$ ) did not reach the $5 \%$ level of significance in case of the head weight and grain weight/plant in both seasons and the weight of 1000 grain in the second seasons. The increases in these traits with increasing plant spacing between quinoa plants might be due to the low below and above ground competition between plants for illumination and nutrients and water. These results are concordant with these obtained by Bhargava et al (2006). The yield of quinoa grain per feddan behaved the converse as the yield components traits behaved. There were decreases in grain yield/fed with increasing the distances between plants up to the widest $(20 \mathrm{~cm}$ apart). However differences were significant in the first year only and these differences among the treatment imposed was also significant, i.e, between 10 and $15 \mathrm{~cm}$ apart and 15 and $20 \mathrm{~cm}$ apart. The reductions are estimated to 117.3 and $3.3 \mathrm{~kg}$ of grain when plant spacing increased from 10 to $15 \mathrm{~cm}$ in the first and second year (25.6 and $0.581 \%)$ and 158.2 and $45.1 \mathrm{~kg}$ when plant spacing increased from $10 \mathrm{~cm}$ to $20 \mathrm{~cm}$ apart in the first and second seasons, respectively (34.53 and 7.98\%) However, these results are concordant with those obtained by Abdel zahar and El-Gendy (2014).

Table (2) : Effect of intra spacing of plants on yield and yield components of quinoa grains.

\begin{tabular}{|c|c|c|c|c|c|c|c|}
\hline $\begin{array}{l}\text { Characters } \\
\text { hill } \\
\text { spacing }\end{array}$ & $\begin{array}{c}\text { Plant } \\
\text { Height } \\
\text { cm }\end{array}$ & $\begin{array}{c}\text { Branches } \\
\text { No. }\end{array}$ & $\begin{array}{l}\text { Head } \\
\text { length } \\
\text { mean } \\
\text { cm }\end{array}$ & $\begin{array}{c}\text { Head } \\
\text { Weight } \\
\text { /plant } \\
\text { g }\end{array}$ & $\begin{array}{c}\text { Grain } \\
\text { Weight } \\
\text { /plant } \\
\text { g }\end{array}$ & $\begin{array}{c}1000 \\
\text { grain } \\
\text { weight } \\
\mathrm{g}\end{array}$ & $\begin{array}{l}\text { Yield } \\
\text { Kg/fed }\end{array}$ \\
\hline & \multicolumn{7}{|c|}{$1^{\text {st }}$ Seasons $(2012 / 2013)$} \\
\hline 10 & $37.31 \mathrm{a}$ & $9.744 \quad b$ & $11.92 \mathrm{~b}$ & $17.56 \mathrm{~b}$ & $11.93 \mathrm{a}$ & $2.24 \mathrm{ab}$ & $458.2 \mathrm{a}$ \\
\hline 15 & $33.88 \mathrm{~b}$ & $10.77 \mathrm{ab}$ & $13.83 \mathrm{a}$ & 19.59 a & $12.74 \mathrm{a}$ & $2.18 \mathrm{~b}$ & $340.9 \mathrm{~b}$ \\
\hline 20 & $31.04 \mathrm{~b}$ & $11.92 \mathrm{a}$ & $13.98 \mathrm{a}$ & $20.21 \mathrm{a}$ & $13.40 \mathrm{a}$ & $2.31 \mathrm{a}$ & $300.0 \mathrm{c}$ \\
\hline \multirow[t]{2}{*}{ LSD 5\% } & 3.28 & 1.3 & 1.13 & 1.14 & N.S & 0.10 & 0.03 \\
\hline & \multicolumn{7}{|c|}{$2^{\text {nd }}$ Seasons (2013/2014) } \\
\hline 10 & $52.19 \mathrm{a}$ & $11.54 \mathrm{a}$ & $14.34 \quad b$ & $20.74 \quad b$ & $13.82 b$ & $2.31 \mathrm{a}$ & $565.5 \mathrm{a}$ \\
\hline 15 & $47.42 \mathrm{~b}$ & $12.83 \mathrm{a}$ & $14.94 \mathrm{~b}$ & 24.99 a & $16.78 \mathrm{a}$ & $2.31 \mathrm{a}$ & $562.2 \mathrm{a}$ \\
\hline 20 & $46.00 \mathrm{~b}$ & $13.74 \mathrm{a}$ & $16.49 \mathrm{a}$ & $26.70 \mathrm{a}$ & $18.43 \mathrm{a}$ & $2.35 \mathrm{a}$ & $520.4 \mathrm{a}$ \\
\hline LSD 5\% & 4.71 & N.S & 1.37 & 3.89 & 2.71 & N.S & N.S \\
\hline
\end{tabular}

\section{3-Effect of inter spacing of rows and intra spacing between plants.}

Result in table (3) presented the interaction effect between the inter and intra spacing on growth behavior and grain yield and its components. 
Table (3) interaction effect of inter and intra spacing on yield and yield components of quinoa grains.

\begin{tabular}{|c|c|c|c|c|c|c|c|c|}
\hline \multicolumn{2}{|c|}{ Characters } & \multirow[b]{2}{*}{$\begin{array}{l}\text { Plant } \\
\text { Height } \\
\text { cm }\end{array}$} & \multirow[b]{2}{*}{$\begin{array}{c}\text { branches } \\
\text { No. }\end{array}$} & \multirow{2}{*}{$\begin{array}{c}\text { Head } \\
\text { length } \\
\text { mean } \\
\text { cm } \\
\end{array}$} & \multirow[b]{2}{*}{$\begin{array}{c}\text { Head } \\
\text { weight } \\
\text { g }\end{array}$} & \multirow{2}{*}{$\begin{array}{c}\text { Grain } \\
\text { weight } \\
\text { /plant } \\
\text { g }\end{array}$} & \multirow{2}{*}{$\begin{array}{c}1000 \\
\text { grain } \\
\text { weight } \\
\mathrm{g} \\
\end{array}$} & \multirow[b]{2}{*}{$\begin{array}{l}\text { Yield } \\
\text { kg/fed }\end{array}$} \\
\hline \multirow[t]{2}{*}{\begin{tabular}{|l|} 
Inter \\
spacing \\
cm
\end{tabular}} & \begin{tabular}{|c|} 
Intra \\
spacing \\
$\mathrm{cm}$
\end{tabular} & & & & & & & \\
\hline & & \multicolumn{7}{|c|}{$1^{\text {st }}$ Seasons (2012 / 2013) } \\
\hline \multirow{3}{*}{20} & 10 & $41.57 \mathrm{a}$ & 9.567 & $11.00 \mathrm{e}$ & $13.39 \mathrm{f}$ & $7.867 \mathrm{c}$ & $2.26 \mathrm{a}$ & $913.3 \mathrm{a}$ \\
\hline & 15 & $35.50 \mathrm{~b}$ & 9.900 & 11.40 & $16.73 \mathrm{e}$ & 9.600 bc & $2.16 \mathrm{a}$ & $512.0 \quad b$ \\
\hline & 20 & 29.30 & 10.30 & 11.20 & $16.00 \mathrm{e}$ & 9.600 bc & $2.30 \mathrm{a}$ & 364.0 \\
\hline \multirow{3}{*}{30} & 10 & 34.43 bc & 10.87 & 10.07 & $20.60 \mathrm{bcd}$ & $13.47 \mathrm{a}$ & $2.200 \mathrm{a}$ & 316.0 \\
\hline & 15 & $\mathrm{bc}$ & 11.00 & $13.00 \mathrm{~cd}$ & $22.10 a b$ & $13.27 \mathrm{ab}$ & $2.200 \mathrm{a}$ & 340.0 \\
\hline & 20 & $32.90 \mathrm{bc}$ & 10.87 & $15.80 \mathrm{ab}$ & $20.00 \mathrm{~cd}$ & $15.33 \mathrm{a}$ & $2.33 \mathrm{a}$ & 356.7 \\
\hline \multirow{3}{*}{40} & 10 & $35.93 \mathrm{ab}$ & $8.800 \mathrm{c}$ & 14.70 bc & $18.70 \mathrm{~d}$ & $14.47 \mathrm{a}$ & $2.26 \mathrm{a}$ & 145.3 \\
\hline & 15 & $32.40 \mathrm{bc}$ & $11.40 \mathrm{~b}$ & $17.10 \mathrm{a}$ & $21.80 \mathrm{abc}$ & $15.37 \mathrm{a}$ & $2.200 \mathrm{a}$ & 170.7 \\
\hline & 20 & $30.93 \mathrm{bc}$ & $14.60 \mathrm{a}$ & $14.93 \mathrm{bc}$ & $22.77 \mathrm{a}$ & $15.27 \mathrm{a}$ & $2.300 \mathrm{a}$ & 179.3 \\
\hline LSD 5\% & & & 2.22 & 1.95 & 1.97 & 3.83 & 0.17 & 0.05 \\
\hline & & \multicolumn{7}{|c|}{$2^{\text {nd }}$ Seasons (2013 / 2014) } \\
\hline \multirow{3}{*}{20} & 10 & $55.07 \mathrm{a}$ & 9.300 & $14.40 \mathrm{~b}$ & $15.50 \mathrm{~d}$ & $9.533 \mathrm{e}$ & $2.30 \mathrm{a}$ & $756.6 \mathrm{a}$ \\
\hline & 15 & $49.33 \mathrm{ab}$ & $9.800 \mathrm{~d}$ & 14.83 & $19.53 \mathrm{~cd}$ & $9.667 \quad \mathrm{e}$ & $2.33 \mathrm{a}$ & $683.9 \mathrm{ab}$ \\
\hline & 20 & $48.80 \mathrm{ab}$ & $11.10 \mathrm{bcd}$ & 15.57 & $22.10 \mathrm{bcd}$ & $12.33 \mathrm{de}$ & $2.43 \mathrm{a}$ & $590.5 \mathrm{~b}$ \\
\hline \multirow{3}{*}{30} & 10 & $53.40 \mathrm{a}$ & $10.93 \mathrm{~cd}$ & 14.30 & $20.37 \mathrm{bcd}$ & $16.77 \mathrm{bcd}$ & $2.26 \mathrm{~b}$ & $617.0 \mathrm{ab}$ \\
\hline & 15 & $47.93 \mathrm{ab}$ & $13.90 \mathrm{abc}$ & $15.07 \mathrm{~b}$ & $25.50 \mathrm{abc}$ & $21.03 \mathrm{ab}$ & $2.30 \mathrm{~b}$ & $619.6 \mathrm{ab}$ \\
\hline & 20 & $47.00 \mathrm{ab}$ & $14.93 \mathrm{ab}$ & $15.80 \mathrm{ab}$ & $26.37 \mathrm{ab}$ & $21.97 \mathrm{a}$ & $2.33 \mathrm{ab}$ & $694.6 \mathrm{ab}$ \\
\hline \multirow{3}{*}{40} & 10 & $48.10 \mathrm{ab}$ & $14.40 \mathrm{abc}$ & $14.33 \mathrm{~b}$ & $26.37 \mathrm{ab}$ & $15.17 \mathrm{~cd}$ & $2.36 \mathrm{ab}$ & $276.1 \quad c$ \\
\hline & 15 & $45.00 \mathrm{~b}$ & $14.80 \mathrm{abc}$ & $14.93 \mathrm{~b}$ & $29.93 \mathrm{a}$ & $19.63 \mathrm{abc}$ & $2.30 \mathrm{~b}$ & 310.2 \\
\hline & 20 & $42.20 \quad b$ & $15.20 \mathrm{a}$ & $18.10 \mathrm{a}$ & $31.63 \mathrm{a}$ & $21.00 \mathrm{ab}$ & $2.30 \mathrm{~b}$ & $395.6 \quad c$ \\
\hline LSD 5\% & & 8.16 & 3.94 & 2.37 & 6.73 & 4.69 & 0.11 & 155.1 \\
\hline
\end{tabular}

Highest grain yield of quinoa was obtained when using the narrowest distance between rows and between plants. More over; at the lowest inter spacing between rows $(20 \mathrm{~cm})$, increasing the intra spacing between plants to from 10 to 15 and $20 \mathrm{~cm}$ ) caused substantial significant decrease in grain yield being 756, 684 and $590 \mathrm{~kg} / \mathrm{fed}$ in the second seasons with significant differences in each seasons. However widening the inter spacing between rows to 30 and up to $40 \mathrm{~cm}$, the increase of the intra spacing from to 15 and up to $20 \mathrm{~cm}$ between hills caused slight significant increase in grain yield of quinoa, This trend was noticed for each of two growing seasons with significant interaction effect of the two factors (inter and intra spacing) in the first seasons. This is not the situation for producing the highest grain yield at the intra spacing between hills. These results is very well accepted because of the even distribution of plants in the field which provid the equidistant plants with better distribution of the required environmental factor as light, water, nutrients, space and the edaphic balance and actives. In other ward, the even distribution of plant may reduce the competention of plants for their essential requests. Morever, this inter and intra spacing produced relatively more grain yield of quinoa than at either widening the inter spacing 30 or 40 $\mathrm{cm}$ and the intra spacing 15 and $20 \mathrm{~cm}$ (Table 1). This trend was noticed in each of the two growing seasons with significantly variable magnitudes. 
The above present situation is more of less reflected on the other studied parameters of litte fluctuation, but came out with the currently studies results which accumulated in grain yield of quinoa.

\section{1- Effect on chemical content of quinoa grain.}

\section{a- Effect of inter spaces of rows}

Results in table (4) indicate that row spacing had appreciable effect on nitrogen and protein concentrations in quinoa grain. Data revealed gradual increases in both nitrogen and protein concentrations with widening the inter spaces between rows up to $40 \mathrm{~cm}$ apart. Moreover differences diminished between $30 \mathrm{~cm}$ and $40 \mathrm{~cm}$ inter spaces between rows.

The increases in both components might be due to plant to plant less competition for available nitrogen in soil. This could be due to more availability and less competition for such wider space around the rows which gave a better chance for plant to absorb such nutrients.

On other hand, phosphorus behaved the reverse, i.e, phosphorus concentration decreased with increasing row spacing indicating the normal antagonistic criterion between nitrogen and phosphorus. Also, the distribution of phosphorus fertilizer around the narrower rows could mining the phosphorus from soil as compared with the wider distance between rows where the phosphorus fertilizer will be spreaded on relatively wider spaces of soil around the plants which may allow more unavailibility of phosphores.

\section{b- Effect intra spacing of plant}

The effect of plant spacing on nitrogen and protein concentrations in quinoa grains was similar to the effect of row spacing. Gradual increases in the concentrations of nitrogen and Protein was associated with increasing plant spacing up to $20 \mathrm{~cm}$. apart. Similar differences between the narrowest $10 \mathrm{~cm}$ apart and $15 \mathrm{~cm}$ apart was greater than between 15 and $20 \mathrm{~cm}$, apart. However, these results were supported by Kamel et al (1967) Potassium concentration followed the same pattern of nitrogen supporting. The less competition between plants grown at wider spacing seemed to be the cause and effect. The data also revealed relative increases in phosphorus concentration with widening plant spacing. (Akbari et al 2011).

The interaction effect of row and plant spacing on nitrogen and protein concentrations in quinoa grain was regular. With increasing row and plant spacing, nitrogen and protein concentrations increased up to the widest $(40 \times 20)$. Although, highest grain was associated with relatively higher protein yield in case of the interacted treatment $(20 \times 10)$ which scored $834.95 \mathrm{~kg}$ of grain/fed and $114.39 \mathrm{~kg}$ of protein/fed, yet, the intensive stand might diminish farmer popularity to apply such intensive population and prepare $(30 \times 20)$ which scored $525.65 \mathrm{~kg}$ of grain and $199.35 \mathrm{~kg}$ protein/fed (table 6). 
Table (4) : Effect of row spacing on some chemical components of quinoa grain

\begin{tabular}{|l|c|c|c|c|}
\hline $\begin{array}{c}\text { Component } \\
\text { Row distance }\end{array}$ & $\mathbf{N} \%$ & Protein $\%$ & $\mathbf{P} \%$ & $\mathbf{K} \%$ \\
\hline $20 \mathrm{~cm}$ & $2.4 \mathrm{~b}$ & $14.2 \mathrm{~b}$ & $0.45 \mathrm{a}$ & $0.60 \mathrm{c}$ \\
\hline $30 \mathrm{~cm}$ & $2.9 \mathrm{a}$ & $17.2 \mathrm{a}$ & $0.41 \mathrm{~b}$ & $0.74 \mathrm{~b}$ \\
\hline $40 \mathrm{~cm}$ & $3.0 \mathrm{a}$ & $17.5 \mathrm{a}$ & $0.34 \mathrm{C}$ & $0.78 \mathrm{a}$ \\
\hline LSD 5\% & 0.1 & 0.6 & 0.01 & 0.02 \\
\hline
\end{tabular}

Table (5) : Effect of plant spacing on some chemical components of

\begin{tabular}{|c|c|c|c|c|}
\hline Component & & & & \\
\hline $\begin{array}{l}\text { Plant } \\
\text { spacing }\end{array}$ & $\mathbf{N} \%$ & Protein \% & P \% & K \% \\
\hline $10 \mathrm{~cm}$ & $2.5 \mathrm{c}$ & $14.6 \mathrm{c}$ & $0.38 \mathrm{c}$ & $0.69 \mathrm{a}$ \\
\hline $15 \mathrm{~cm}$ & $2.7 \mathrm{~b}$ & $16.2 \mathrm{~b}$ & $0.39 \mathrm{~b}$ & $0.71 \mathrm{a}$ \\
\hline $20 \mathrm{~cm}$ & $3.1 \mathrm{a}$ & $18.1 \mathrm{a}$ & $0.41 \mathrm{a}$ & $0.72 \mathrm{a}$ \\
\hline LSD 5\% & 0.1 & 0.8 & 0.009 & N.S \\
\hline
\end{tabular}

Table (6) : Effect of plant spacing on some chemical components of quinoa grain

\begin{tabular}{|c|c|c|c|c|c|c|}
\hline \multicolumn{2}{|c|}{ Component } & \multirow[b]{2}{*}{ N \% } & \multirow[b]{2}{*}{ Protein \% } & \multirow[b]{2}{*}{ P \% } & \multirow[b]{2}{*}{ K \% } & \multirow{2}{*}{$\begin{array}{c}\text { Yield of } \\
\text { protein/fed } \\
(\mathrm{kg})\end{array}$} \\
\hline $\begin{array}{l}\text { Row } \\
\text { spasing }\end{array}$ & $\begin{array}{c}\text { plant } \\
\text { spacing }\end{array}$ & & & & & \\
\hline \multirow{3}{*}{$20 \mathrm{~cm}$} & $10 \mathrm{~cm}$ & $2.2 \mathrm{~g}$ & $12.7 \mathrm{~g}$ & $0.45 c$ & $0.57 \mathrm{e}$ & 114.39 \\
\hline & $15 \mathrm{~cm}$ & $2.4 \mathrm{f}$ & $14.2 \mathrm{fg}$ & $0.45 \mathrm{~b}$ & $0.60 \mathrm{de}$ & 84.90 \\
\hline & $20 \mathrm{~cm}$ & $2.7 \mathrm{de}$ & $15.8 \mathrm{de}$ & $0.47 \mathrm{a}$ & $0.6 \mathrm{~d}$ & 75.41 \\
\hline \multirow{3}{*}{$30 \mathrm{~cm}$} & $10 \mathrm{~cm}$ & $2.7 \mathrm{de}$ & $16.0 \mathrm{de}$ & $0.40 \mathrm{e}$ & $0.73 \mathrm{c}$ & 74.64 \\
\hline & $15 \mathrm{~cm}$ & $2.8 \mathrm{~cd}$ & $16.6 \mathrm{~cd}$ & $0.40 \mathrm{de}$ & $0.74 \quad b c$ & 79.65 \\
\hline & $20 \mathrm{~cm}$ & $3.2 a b$ & $18.9 \mathrm{ab}$ & $0.42 \mathrm{~cd}$ & $0.74 \quad b c$ & 99.39 \\
\hline \multirow{3}{*}{$40 \mathrm{~cm}$} & $10 \mathrm{~cm}$ & 2.5 ef & 15.0 ef & $0.33 \mathrm{~g}$ & $0.75 \mathrm{bc}$ & 28.61 \\
\hline & $15 \mathrm{~cm}$ & $3.1 \mathrm{bc}$ & $17.9 \mathrm{bc}$ & $0.33 \mathrm{~g}$ & $0.78 \mathrm{ab}$ & 43.04 \\
\hline & $20 \mathrm{~cm}$ & $3.3 \mathrm{a}$ & $19.7 \mathrm{a}$ & $0.36 \mathrm{f}$ & $0.81 \mathrm{a}$ & 56.63 \\
\hline \multicolumn{2}{|c|}{ LSD 5\% } & 0.2578 & 1.530 & 0.016 & 0.039 & \\
\hline
\end{tabular}

Table (7) : Effect of plant spacing on some chemical components of quinoa grain

\begin{tabular}{|l|c|c|c|c|}
\hline \multicolumn{2}{|c|}{ Treatment } & \multirow{2}{*}{ Yield/fed } & $\begin{array}{c}\text { Protein conc. } \\
\%\end{array}$ & $\begin{array}{c}\text { Yield of } \\
\text { protein/fed } \mathbf{( k g})\end{array}$ \\
\hline $\begin{array}{l}\text { Row spacing } \\
(\mathbf{c m})\end{array}$ & $\begin{array}{c}\text { Plant spacing } \\
\mathbf{( c m )}\end{array}$ & & 13.7 & 114.39 \\
\hline \multirow{3}{*}{$20 \mathrm{~cm}$} & $10 \mathrm{~cm}$ & 834.95 & 14.2 & 84.90 \\
\cline { 2 - 5 } & $15 \mathrm{~cm}$ & 597.95 & 15.8 & 75.41 \\
\hline \multirow{3}{*}{$30 \mathrm{~cm}$} & $20 \mathrm{~cm}$ & 477.25 & 16.0 & 74.64 \\
\cline { 2 - 5 } & $10 \mathrm{~cm}$ & 466.50 & 16.6 & 79.05 \\
\cline { 2 - 5 } & $15 \mathrm{~cm}$ & 479.80 & 18.9 & 99.35 \\
\hline \multirow{3}{*}{$40 \mathrm{~cm}$} & $20 \mathrm{~cm}$ & 525.65 & 15.0 & 28.01 \\
\cline { 2 - 5 } & $10 \mathrm{~cm}$ & 190.70 & 17.9 & 43.04 \\
\cline { 2 - 5 } & $15 \mathrm{~cm}$ & 240.45 & 19.7 & 56.63 \\
\hline
\end{tabular}




\section{REFERENCES}

Abd-El-Zahar, Sh. R and E.K. Gendy (2014): Effect of plant density and mineral and bio-nitrogen fertilization on intercropping faba bean with sugar beet.Egypt. J. of Appl. Sci. 29 (7) 352-366.

Akbari, P., Ghalavand, A., Modarres Samary, A. M and M. Agha Alikhani (2011): The effect of biofertilizers, nitrogen fertilizer and farmyard manure on grain yield and seed quality of sunflower. Journual of Agric Tech 20 n Vol 7 (1) 173-184.

Atul.B., S.srivastava (2013) : cropped (C.F, Quinoa Botany production) CABI.

Aufhammer, W., Kaul, H. P., Herz, P., Nalborezyk, E., Dalbiak, and M. Gontarczyk (1995): Grain yield formation and nitrogen uptake of amaranth. Eur.J. Agron 4, 379-386.

Bhargava.A.; Shukla. S. and D. Ohiri (2006):Chenopodium quinoa. An Indian perspective Industrial crops and products 23 PP73-87.

Bubenheim, D (1991).Plants for water recgling, Oxygen regeneration, and food production. Waste Mangement Res. 9:435-443.

Brown, J.D. and Lillel and, O. (1946): Rapid determination of potassium and sodium in plant material and soil extracts by phlame photometry. Proc. Amer. Soc Hort. Sci. 48, 341-345.

Freed.R.D. ( 1991): MSTATC Microcomputer statistical program Michigan state university. East Lansing. M ichigan, U.S.A.

Galwey, N. W. and J. Risi (1984): Development of the Andean grain crop quinoa for Production in Britain.Univ. of Cambridge Anna.Rpt., Cambridge, U.K.

Gimplinger, D. M., Dobos, G., Shonlechner.C. and H. P. Kaul. (2007): Yield and quality of grain amaranth sp.) in Eastern Austria. Plant soil environ., 53: 105-112.

Henderson, T. L., Schneiter, A. A. and Riveland (1993): Row spacing and population effects on yield of grain amaranth in North Dakota. Janic. J. and J. E. Simon (eds.) New crops. Wiley New York.

Henderson, T., B. Johnson and A. Schneither (2000): Row Spacing, plant population and Cultivar effect on grain amaranth in the Northeen Great Plains.Agron.J.,92:329-336.

Jacobsen, S.E.; Jargonsen. I., and O.Stplen (1994): Cultivation of quinoa under temperate Climatic conditions in Denmark. J. Agric. Sci: 122,4752.

Le -Clerg, E. L., Leonard, W. H. and A. C. Clark, (1962): Field plot technique Durgess Publishing com. U.S.A. and Eb.

Malligawadit, L.H and V.C Patil (2001): Effect of plant density and planting geometry on growth and yield of grain amaranths Kamataka J. Agric. Sci 14:11-17.

Myers, R. L. and P.H. Putnam (1998): Growing grain amaranth as specialty crop. The University of Minnesota extension service. 
Oelke, E. A., Putnam, D. H, Teynor. T.M. and E.S. Oplinger (1992): Alternative field crops manual. University of Minnesota extension service university of Minnesota Extension service, centre for Alternarnative plant and animal products.

Olofintoye, J.A.T.; Adeniyi. H.A and Adetula O.A. (2011): Effect on the growth and yield of Grain Amaranth (AmaranthusCruentus) Agricultural Journal 6(6): 366-568.

Rojas, W., Barriga. P and H. Figueroa (2004): Multivariate analysis of genetic diversity of Bolivian quinoa germ plasm. Food Rev. Int 14 (1-2) 9-23.

Schlick., G and D. L. Bubenheim (2005): Quinoa: Candidate crop for NASA'S Controlled Ecological life support systems file// E:\ From\% 202-2005 A_project $\backslash$ Quinoa $\backslash$ Quinoa\% 20 Crop\% 20.

Sherif, Sahar.A.; A. A. Zohary and Ibrahim, Sahart. (2005): Effect of planting dates and densities of maize intercropping with ground on growth, yield and yield components of both crops. Arab Univ. J. A.gric. Sci., Ain Shams Univ., Cairo, 13 (3) : 771-791.

Smitha Patel, P. A., Alacundagi, S. C.; Mansur, C. P.; Kubsad V. S.; Hosamani, S. V.and S.N. Megeri (2011): Effect of row spacing and seed economics of amaranth gentypes. Karnataka. J. A. gric. Sci. 24 (5: 651-653.

Spehar. C. r. and J.E.D.S. Rocha (2009): Effect of sowing density on plant growth and development of Quinoa, genotype 4.5, in the Brazilian Savannah Highlands Biosci. J.,Uberlandia, Vol. 25,.4 P.53-58.

Sweeney, R. A., and P. R. Rexroad (1987): Comparison of LECOFP-228 “ Nitrogendetermination" with AOAC copper analyst. Kjeldahl method for crude protein.J.AOAC International 70, 1028-1030.

Troug, E. and A. H. Meyer (199r): Improvement in the deiness colorimetric method for phosphorus and arsenic. Ind. Eng. Chem., Anal. Ed., 1: 136-139. 
تأثير اختلاف المسافات بين السطور وبين النباتات علي نمو وانتاجية وجودة نبات

الكينوا

سيف الدين عطا الله سيف* ، حسن رمضان أحمد الايبة** , أحمد سـعيد مصطفي كامل * و

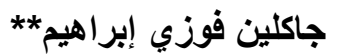

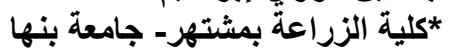

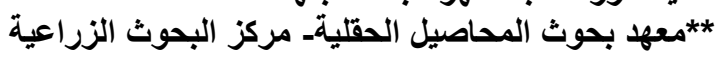

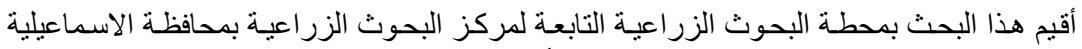

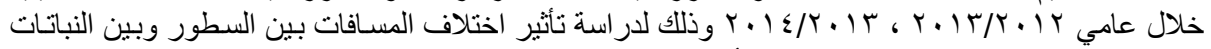

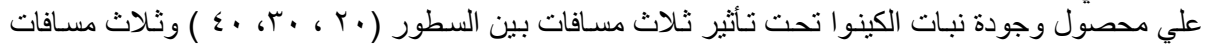

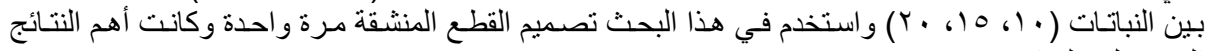

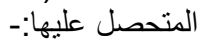

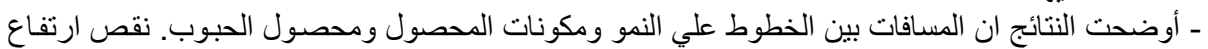

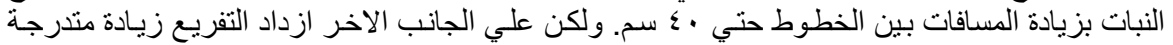

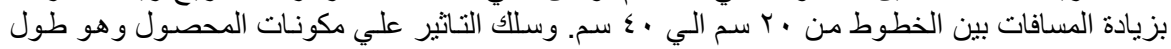

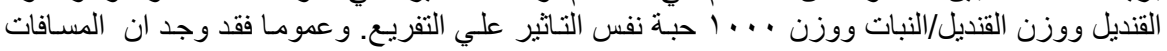

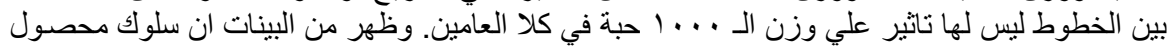

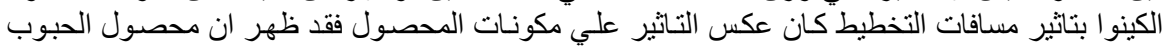

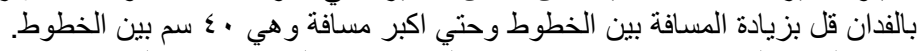

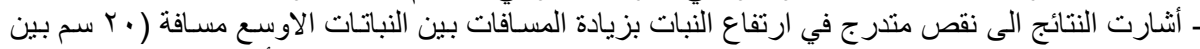

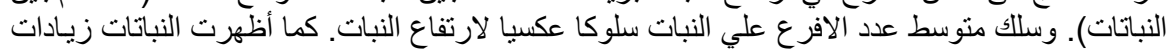

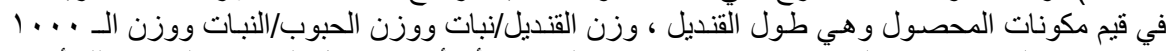

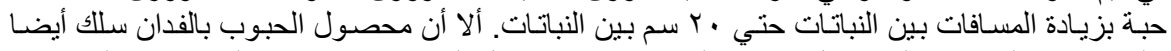

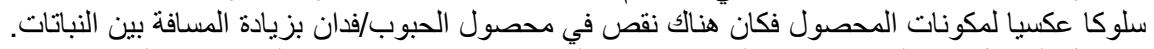

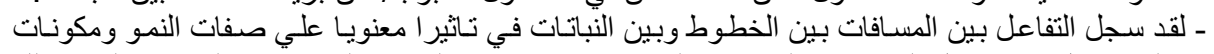

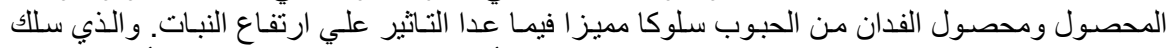

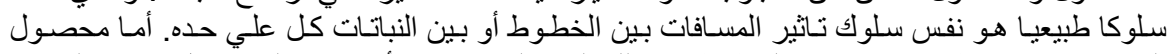

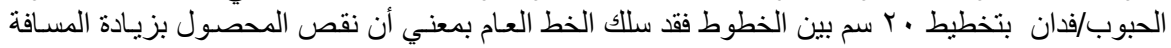

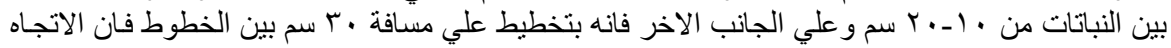

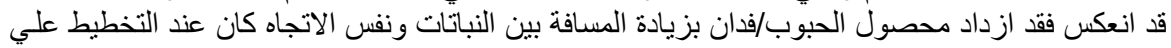

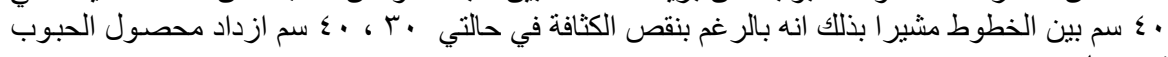

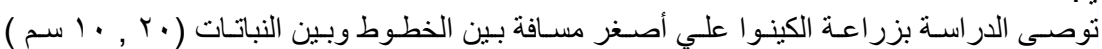

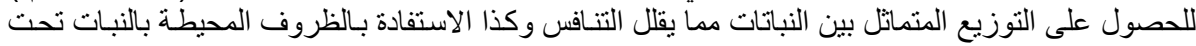
ظروف البيئة المصرية للحصول على اعلى انتاجية. 